\title{
The Impact of Relationship Marketing on Customer Loyalty at Plaza
}

\section{Toyota Workshop Bandung}

\author{
Putri Yuliastuti \\ Master of Management at Bakrie University, Jakarta, Indonesia
}

\begin{abstract}
Article Info
Volume 8, Issue 2

Page Number : 56-70
\end{abstract}

Publication Issue

March-April-2021

\section{Article History}

Accepted : 02 March 2021

Published : 11 March 2021

\section{ABSTRACT}

This research was conducted to study the impact of relationship marketing on customer loyalty in a form of service consistency provided by the Plaza Toyota Workshop Bandung to its customers. This research used 4 (four) independent variables (customer's trust, service commitment, service communication and conflict handling) on to the dependent variable (customer loyalty). This research was conducted on customers of the Plaza Toyota Workshop Bandung who routinely use auto repair services at the workshop. This research used a quantitative approach to understand and define the variables standing that are studied in this research and the influence between one variable and another. The data collecting technique used in this research is by distributing questionnaires to 100 samples. The results showed that customer's trust gave zero impact in gaining customer loyalty. Meanwhile, service commitment, service communication, and conflict handling are in some ways correlated with customer's loyalty. According to the results of the analysis which based on the results of the average index calculation, customers have no doubt about the indicators that build their trust to the Plaza Toyota Workshop Bandung, in other word, customers automatically trust Plaza Toyota Workshop Bandung. While the other three variables have influence. And the indicators of these three variables can be used as a prove based on the results of the item ranking questions. Based on these results, Plaza Toyota Workshop Bandung must be more focused on developing these three variables in order to build customer loyalty.

Keywords : Relationship Marketing, Customer Loyalty, Plaza Toyota Workshop Bandung.

\section{INTRODUCTION}

Transportation currently experiencing development at the same pace as the development of infrastructure in Indonesia. This development that goes hand in hand and continuously causes Indonesian: Single Agent Brand (ATPM) to experience quite tough competition in the automotive market. This indicates that all ATPMs are competing to increase sales in order to stay in the competition. 
Beside having to increase sales, They also have to face the increasing target of after sales, which includes repair and maintenance of the product. One of the largest automotive ATPMs in Indonesia is PT. Toyota Astra Motor (TAM). According to the data of car sales in January 2019 (Taufan, 2019), number of cars sold with the Toyota brand managed to be in the first place with 25,092 units sold (30.89\%). PT. TAM (Toyota Astra Motor) as the market leader in 2019 should maintain the position it has achieved, namely by fulfilling customers' satisfaction to gain customers' loyalty. One way to gain customer loyalty is by reminding customers to carry out routine service at Toyota's authorized workshops. This strategy is carried out by a Maintenance Reminder Appointment (MRA) by contacting customers whose car have to be maintenanced via phone calls or other media of communication (Toyota Astra Motor, 2019).

One of the official workshops owned by Toyota in which applies this Maintenance Reminder Appointment (MRA) strategy is the Plaza Toyota Workshop Bandung. According to the West Java regional sales achievement report, the Plaza Toyota Dealer Bandung was ranked 8th out of 10 authorized dealers in the West Java region with a sales rate of $98 \%$ in August 2019 and according to whole West Java workshop sales achievement data, Plaza Toyota Workshop Bandung ranked in the top 10 (top ten) when compared to 31 workshops in the West Java region in the 2019 on Customer Paid Unit Service. It can be concluded that Plaza Toyota Workshop Bandung has done an important contribution in achieving the annual performance of PT. TAM (Toyota Astra Motor) in West Java.

Berry, L.L. (1982), said that Relationship Marketing is a strategy to attract, grow and maintain relationships with customers. Based on that understanding, it can be seen that the strategy executed by PT. TAM (Toyota Astra Motor) through a Maintenance Reminder Appointment (MRA) is a form of relationship marketing of PT. TAM (Toyota Astra Motor) to its customers. According to Ndubisi (2007), the concept of Relationship Marketing has 4 (four) main keys, those keys are trust, commitment, conflict handling, and communication. Those four main keys are then associated with customer loyalty. Based on the five keys that exist in relationship marketing, company owners are encouraged to formulate values or sacrifices in building a relationship with loyal customers (Ndubisi, 2007).

PT TAM's Maintenance Reminder Appointment (MRA) strategy is not sufficient enough to prove that there is a strong correlation between relationship marketing and customer loyalty. Based on data on routine maintenance and general repair at the Plaza Toyota Workshop Bandung, (2019) it is known that in June 2019 the number of customers who had been contacted to carry out routine maintenance was 662 customers, but only 254 customers that actually came to perform routine maintenance at Plaza Toyota Workshop Bandung. This proves that there are problems so that customer loyalty is not created at Plaza Toyota Workshop Bandung. Based on the previous background fact, it encourages researchers to conduct a research on "The Impact of Relationship Marketing on Customer Loyalty at Plaza Toyota Workshop Bandung."

\subsection{Problem Formulation}

Based on the background description, the researcher formulates the problem "Does Relationship Marketing affect customer's loyalty" as for the elaboration of the main problems are as follows;

1.2.1 Does trust affect customer loyalty at Plaza Toyota Workshop Bandung?

1.2.2 Does commitment affect customer loyalty at Plaza Toyota Workshop Bandung?

1.2.3 Does communication affect customer loyalty at Plaza Toyota Workshop Bandung? 
1.2.4 Does conflict handling affect customer loyalty at Plaza Toyota Workshop Bandung?

1.2.5 Do trust, commitment, communication and conflict handling have a simultaneous effect on customer loyalty at Plaza Toyota Workshop Bandung?

\subsection{Research Objectives}

Based on the formulation of the problems above, it encourages the researcher to find out more about the impact of relationship marketing on customer loyalty, therefore the research objectives are;

1.3.1 To determine the effect of trust on customer loyalty at Plaza Toyota Workshop Bandung

1.3.2 To determine the effect of commitment to customer loyalty at Plaza Toyota Workshop Bandung

1.3.3 To determine the effect of communication on customer loyalty at Plaza Toyota Workshop Bandung

1.3.4 To determine the effect of conflict handling on customer loyalty at Plaza Toyota Workshop Bandung

1.3.5 To determine the effect of trust, commitment, communication and conflict handling simultaneously on customer loyalty at Plaza Toyota Workshop Bandung

\subsection{Research Benefits}

\subsubsection{Theoretical Benefits}

\section{a. Benefits for Researchers}

This study is useful for researchers to broaden knowledge, especially in the field of management, specifically in the scope of relationship marketing, regarding the influence of trust, commitment, communication and conflict handling on customer loyalty, deepening the theories that have been studied and apply those theories in real life.

\section{b. Benefits for Other Researchers}

This research can be used as a reference for other researchers and add insight into the study of the effect of relationship marketing on customer loyalty.

\subsubsection{Practical Benefits}

\section{a. Benefits for the Company}

Based on research results conducted by researchers, it is hoped that it can be useful for Plaza Toyota Workshop Bandung in determining strategies, designing policies and creating programs that aim to increase customer loyalty at Plaza Toyota Workshop Bandung.

\section{b. Benefits for Consumers}

This research is beneficial for consumers in the future to get better service when they take their vehicles to routine maintenance at Plaza Toyota Workshop Bandung.

\section{c. Benefits for Society}

This research is beneficial for the community since it gives information about how routine vehicle maintenance services are at $t$ Plaza Toyota Workshop Bandung.

\section{Relationship Marketing}

According to Tandjung (2004: 89), Relationship Marketing is growth, development, and maintenance in the long term that creates cost-effective relationships with customers, suppliers, employees, and other partners that are mutually beneficial. According to Chan (2003: 6), the purpose of Relationship Marketing is to find life time value (LTV), increase the life time value (LTV) in each group and find new customers. According to Kotler and Armstrong (1996, p.579-582) relationship marketing has the benefit of saving costs that customers spend, learning what customers need and want individually, building strong 
relationships between business entities and their customers.

According to Morgan and Hunt (1994); Churchill and Surprenant (1982) in Ndubisi (2007), relationship marketing is influenced by four (4) variables, those are as follow;

\section{Trust}

Trust is the foundation of a partnership, that is, there are parties who have the desire to bind themselves to a relationship. According to Ndubisi (2007), building trust can be done by keeping promises to customers, providing security for every transaction, providing quality service and showing a caring attitude towards customers.

\section{Commitment}

Commitment is a desire for a continuous relationship based on trust between one party and another. According to (Tjiptono, 2005: 415) commitment is the desire between the two parties to build and maintain a relationship that is considered important and reflected in cooperative behavior and active actions to establish and maintain relationships.

\section{Communication}

Communication can be formed by providing accurate and reliable information. This information can be in the form of changes in the services offered. Communication is also needed when there are problems between the company and its customers (Ndubisi, 2007).

\section{Conflict Handling}

Handling problems (Conflict Handling) is the ability to prevent, minimize and resolve conflicts that have occurred. If the conflict is ignored, it will become a serious problem for the company and have the potential to reduce performance if the conflict is not resolved. According to (Bramson; 2005), when a customer face a problem even though he is only slightly disappointed, the company quickly shows its identity. Companies must be able to view service recovery as an opportunity that must be handled very well because customer complaints are one of the opportunities to create strength in the relationship that exists between the company and its customers.

\section{Customer loyalty}

Amin Widjaja (2008: 6) states that customer loyalty is customer attachment to a brand, shop, manufacturer, service provider, or other entity based on a favorable attitude and good responses such as repeat purchases. The existence of loyal customers is able to form a situation where these customers will make repeat purchases, buy these products continuously and in larger quantities and recommend these products to relatives (Hayes, 2008: 22)

\section{Relationship of Relationship Marketing to Customer Loyalty}

According to Schiffman (2000) the relationship of Relationship Marketing to customer loyalty is to develop customer commitment and loyalty to the services and products of the business entity. To achieve Relationship Marketing, business entities need to create strong relationships with customers, by emphasizing long-term ties, making customers comfortable.

Based on the relationship between the independent variable, namely Relationship Marketing and the dependent variable, namely customer loyalty, the hypothesis is proposed:

H1: Trust affects customer loyalty at Plaza Toyota Workshop Bandung

H2: Commitment affects customer loyalty at Plaza Toyota Workshop Bandung 
H3: Communication affects customer loyalty at Plaza Toyota Workshop Bandung

H4: Conflict handling affects customer loyalty at Plaza Toyota Workshop Bandung

H5: Trust, commitment, communication and conflict handling have a simultaneous impact on customer loyalty at Plaza Toyota Workshop Bandung.

\section{RESEARCH METHODS}

This research uses quantitative methods (quantitative). This study consists of variable $\mathrm{X}$ as an independent variable, namely the Relationship Marketing variable which consists of 4 dimensions, namely trust, commitment, communication and conflict handling on variable $\mathrm{Y}$ as the dependent variable, namely customer loyalty. The object of this research is Plaza Toyota Workshop Bandung.

This study used data collection methods in 3 (three) ways, first was interviewing the head of the workshop, service officers at $t$ Plaza Toyota Workshop Bandung and some customers who aim to explore and seek deeper information about Plaza Toyota Workshop Bandung, second was distributing 100 copies of questionnaires using Likert scale to customers who carried out routine vehicle maintenance at Plaza Toyota.

Workshop Bandung and last one was collecting secondary data containing company documents both regarding customer databases, company history, and organizational structure of Plaza Toyota Workshop Bandung.

The population in this study are all customers who carry out routine maintenance of their Toyota brand vehicles at Plaza Toyota Workshop Bandung. In determining the research sample, the researcher used Slovin opinion which assumed that the population was normally distributed (Umar, 2011). The Slovin formula is shown below (Umar, 2011).

$$
n=\frac{\mathrm{N}}{1+\mathrm{N} e^{2}}
$$

Note:

$\mathrm{N}$ : Population size

$\mathrm{N}$ : Sample size

e : Leniency percentage of inaccuracy due to sampling error that can still be tolerated or desired

Based on the formula above, the number of samples to be studied can be calculated as follows:

$$
\begin{aligned}
& n=\frac{2237}{1+223710 \% 0^{2}} \\
& \mathrm{n}=100
\end{aligned}
$$

Based on the calculations above, it can be seen that the number of samples about to be used in this study with an error rate of $10 \%$ is 100 people.

This study uses multiple linear regression analysis method which is used to determine how much influence relationship marketing has on customer loyalty at $t$ Plaza Toyota Workshop Bandung. The multiple regression method is using the following formula:

$$
\mathrm{Y}=\mathrm{a}+\beta 1 \mathrm{X} 1+\beta 2 \mathrm{X} 2+\beta 3 \mathrm{X} 3+\beta 4 \mathrm{X} 4+\mathrm{e}
$$

$\mathrm{Y}=$ Consumer loyalty

$\mathrm{A}=$ Constanta

$\beta 1-\beta 5=$ Multiple regression coefficient

$\mathrm{X} 1=$ Trust

$\mathrm{X} 2$ = Communication

$\mathrm{X} 3=$ Commitment

$\mathrm{X} 4$ = Conflict handling

$\mathrm{e}=$ Standard error

The data in this study were processed statistically using the SPSS ver. 25 program. Valid data were then processed for reliability testing, classical assumption tests consisting of normality test, linearity test, multicollinearity test, heteroscedasticity test, multiple 
linear regression test and hypothesis testing consist of partial significance test (T-test), joint variable test (Ftest) and the coefficient of determination (R2).

\section{DISCUSSION}

\section{Respondent Characteristics}

Based on the distributed questionnaire, the respondents were divided into 54 male respondents and 46 female respondents. The ages of the respondents in this study were grouped into 5 categories, category of respondents aged 17-25, 26-35, 36-45, 46-55, and 56-65. Based on the results of the study, most respondents were aged 2635 , about 37 respondents, aged $17-25$ as many as 30 respondents, ages 36-45 as many as 29 respondents, aged $46-55$ as many as 3 respondents, and aged $56-65$ as many as 1 respondent.

Based on the research results under the criteria of the type of work, it is known that the most respondents are working as private employees as many as 66 respondents, entrepreneurship as many as 21 respondents, students as many as 6 respondents, civil servants as many as 3 respondents, freelance as many as 2 respondents and housewife as many as 2 respondents.

Based on the results of the research, the type of vehicle that carry out routine service the most, Avanza, are 23 vehicles and the type of routine service that is mostly carried out is regular routine service of $10,000 \mathrm{~km}$, about 37 respondents.

\section{Validity and Reliability Test}

Before distributing the questionnaire, the researcher conducted a test distribution on the questionnaire given to 30 respondents. This questionnaire test was conducted to test the validity and reliability of the questions on the questionnaire. The validity test conducted by the researcher was carried out on 17 questions on the independent variable which were divided into 4 types of variables, and 2 questions on the dependent variable which were divided into 1 type of variable. The results of the validity test are;

\begin{tabular}{|c|c|c|c|}
\hline $\begin{array}{c}\text { Questions } \\
\text { (Item) }\end{array}$ & $\mathbf{R}_{\text {count }}$ & $\begin{array}{c}\mathbf{R}_{\text {table }} \mathbf{5 \%} \\
(\mathbf{3 0})\end{array}$ & Criteria \\
\hline KP1 & 0.444 & 0.361 & Valid \\
\hline KP2 & 0.396 & 0.361 & Valid \\
\hline KP3 & 0.677 & 0.361 & Valid \\
\hline KP4 & 0.581 & 0.361 & Valid \\
\hline KP5 & 0.722 & 0.361 & Valid \\
\hline KP6 & 0.727 & 0.361 & Valid \\
\hline $\begin{array}{c}\text { Questions } \\
\text { (Item) }\end{array}$ & $\mathbf{R}_{\text {count }}$ & $\begin{array}{c}\mathbf{R}_{\text {table }} \mathbf{5 \%} \\
\text { (30) }\end{array}$ & Criteria \\
\hline KL1 & 0.874 & 0.361 & Valid \\
\hline KL2 & 0.874 & 0.361 & Valid \\
\hline KL3 & 0.721 & 0.361 & Valid \\
\hline KL4 & 0.691 & 0.361 & Valid \\
\hline
\end{tabular}

\begin{tabular}{|l|l|l|l|}
\hline $\begin{array}{c}\text { Questions } \\
\text { (Item) }\end{array}$ & \multicolumn{1}{|c|}{$\mathbf{R}_{\text {count }}$} & $\begin{array}{c}\text { Rtable 5\% } \\
\mathbf{( 3 0 )}\end{array}$ & Criteria \\
\hline KoL1 & 0.643 & 0.361 & Valid \\
\hline KoL2 & 0.830 & 0.361 & Valid \\
\hline KoL3 & 0.701 & 0.361 & Valid \\
\hline KoL4 & 0.820 & 0.361 & Valid \\
\hline $\begin{array}{c}\text { Questions } \\
\text { (Item) }\end{array}$ & $\mathbf{R}_{\text {count }}$ & $\mathbf{R}_{\text {table }} \mathbf{5 \%}$ & Criteria \\
\hline $\begin{array}{c}\text { PKP1 } \\
\text { (30) }\end{array}$ & 0.851 & 0.361 & Valid \\
\hline $\begin{array}{c}\text { PKP2 } \\
\text { PKP3 }\end{array}$ & 0.900 & 0.361 & Valid \\
\hline $\begin{array}{c}\text { Questions } \\
\text { (Item) }\end{array}$ & $\mathbf{R}_{\text {count }}$ & 0.361 & Valid \\
\hline $\begin{array}{c}\text { LP1 } \\
\text { LP2 }\end{array}$ & 0.853 & 0.361 & Valid \\
\hline (30) & 0.361 & \\
\hline
\end{tabular}

It was obtained Rtable 0.361 which the number was used for the amount of $\mathrm{N}=30$ with a significance level of $5 \%$. Based on the comparison of the Rtable and also 
the Rcount, it can be concluded that the results of the overall calculation of Rcount $>$ Rcount indicate that the entire questionnaire in this study is considered valid and can be used as a research instrument.

Reliability test was done by looking for Cronbach's Alpha value. If the Cronbach's Alpha value is $>0.60$, the reliability test results are considered reliable.

\begin{tabular}{|c|c|c|c|}
\hline Variable & $\begin{array}{c}\text { Cronbach's } \\
\text { Alpha } \\
\text { Value }\end{array}$ & $\begin{array}{c}\text { Comparison } \\
\text { Results }\end{array}$ & Value \\
\hline Trust (X1) & 0.643 & $>0.60$ & Reliable \\
\hline $\begin{array}{c}\text { Commitment } \\
\text { (X2) }\end{array}$ & 0.802 & $>0.60$ & Reliable \\
\hline $\begin{array}{c}\text { Communication } \\
\text { (X3) }\end{array}$ & 0.728 & $>0.60$ & Reliable \\
\hline $\begin{array}{c}\text { Conflict } \\
\text { Handling (X4) }\end{array}$ & 0.787 & $>0.60$ & Reliable \\
\hline $\begin{array}{c}\text { Customer } \\
\text { Loyalty (X5) }\end{array}$ & 0.647 & $>0.60$ & Reliable \\
\hline
\end{tabular}

Based on the calculation of the reliability test results, it was known that all variables have a Cronbach's Alpha value 0.60 which means that the questionnaire is reliable.

\section{Classic Test Results}

After the results of the calculation were valid and reliable, the researchers collected data by distributing questionnaires to 100 respondents who researcher met directly at Plaza Toyota Workshop Bandung. After the data was collected, the researcher tabulated and calculated the data that have been obtained.

\section{Normality Test Results}

This test was done by looking at the profitability of Kolmogorof-Smirnov $\mathrm{Z}$ statistics. If the level of profitability was $<0.05$, then the residual value of a regression was not normally distributed, and vice versa. Based on the results of the normality test, the following results were obtained:

\begin{tabular}{llr} 
& & \multicolumn{1}{c}{$\begin{array}{c}\text { Unstandardi } \\
\text { zed } \\
\text { Residual }\end{array}$} \\
\hline $\mathrm{N}$ & & 127 \\
\hline Normal Parameters ${ }^{\mathrm{a}, \mathrm{b}}$ & Mean & .0000000 \\
\cline { 2 - 3 } & Std. & 1.06189416 \\
& Deviation & .070 \\
\hline \multirow{2}{*}{ Most Extreme Differences } & Absolute & .051 \\
\cline { 2 - 3 } & Positive & -.070 \\
\cline { 2 - 3 } & Negative & .070 \\
\hline Test Statistic & & $.200^{\mathrm{c}, \mathrm{d}}$ \\
\hline Asymp. Sig. (2-tailed) & &
\end{tabular}

It can be seen that the calculation results in the Asymp. Sig (2-tailed) table shows a result of 0.200 . This figure shows $>0.05$ which proves the regression residual value has been normally distributed.

\section{Linearity Test Results}

The researcher used the linearity test in order to find out whether the two variables had a significant linear relationship or not. A good correlation should have a linear relationship between the independent variable $(\mathrm{X})$ and the dependent variable $(\mathrm{Y})$.

The basis for decision making in the linearity test can be done in two ways, Which are

a. Comparing Significance Value (Sig.) With 0.05

1. If the value of Deviation from Linearity Sig. > 0.05, then there was a significant linear relationship between the independent variable and the dependent variable. 
2. If the value of Deviation from Linearity Sig. $<0.05$, then there was no significant linear relationship between the independent variable and the dependent variable.

b. Comparing the Fcount value with the Ftable

1. If the value of Fcount $<$ Ftable, then there was a significant linear relationship between the independent variable and the dependent variable.

2. If the value of Fcount > Ftable, then there was no significant linear relationship between the independent variable and the dependent variable.

The calculation results of the linearity test can be seen in the table below;

4. If the value of Fcount > Ftable, then there was no significant linear relationship between the independent variable and the dependent variable.

The calculation results of the linearity test can be seen in the table below;

The linearity test results of the variable customer trust on customer loyalty

Based on the calculation results, it could be seen that the Deviation from Linearity Sig. $>0.05,0.117$ to be exact, then there was a significant linear relationship between the customer trust variable and the customer loyalty variable.

- The linearity test results of the service commitment variable on customer loyalty

Based on the calculation results, it could be seen that the Deviation from Linearity Sig. > 0.05, 0.244 to be exact, then there was a significant linear relationship between the service commitment variable and the customer loyalty variable.

- The linearity test results of service communication variables on customer loyalty

\begin{tabular}{|c|c|c|c|c|c|c|c|}
\hline & \multicolumn{7}{|c|}{ ANOVA Table } \\
\hline & & & $\mathrm{Su}$ & & & & \\
\hline & & & $\mathrm{m}$ & & $\mathrm{Me}$ & & \\
\hline & & & of & & an & & \\
\hline & & & $\mathrm{Sq}$ & & $\mathrm{Sq}$ & & \\
\hline & & & uar & $\mathrm{d}$ & uar & & \\
\hline & & & es & $f$ & $\mathrm{e}$ & $\mathrm{F}$ & Sig. \\
\hline Total & Bet & (Comb & 30. & 1 & 2.5 & 1.56 & .111 \\
\hline Custo & wee & ined) & 143 & 2 & 12 & 7 & \\
\hline mer & $\mathrm{n}$ & Lineari & 2.4 & 1 & 2.4 & 1.52 & .220 \\
\hline Loyal & Gro & ty & 40 & & 40 & 2 & \\
\hline ty ${ }^{*}$ & ups & Deviat & 27. & 1 & 2.5 & 1.57 & .117 \\
\hline Total & & ion & 703 & 1 & 18 & 1 & \\
\hline Custo & & from & & & & & \\
\hline mer & & Lineari & & & & & \\
\hline Trust & & ty & & & & & \\
\hline & With & & 182 & 1 & 1.6 & & \\
\hline & Grou & & .73 & 1 & 03 & & \\
\hline & & & 9 & 4 & & & \\
\hline & Total & & 212 & 1 & & & \\
\hline & & & .88 & 2 & & & \\
\hline & & & 2 & 6 & & & \\
\hline
\end{tabular}




\section{ANOVA Table}

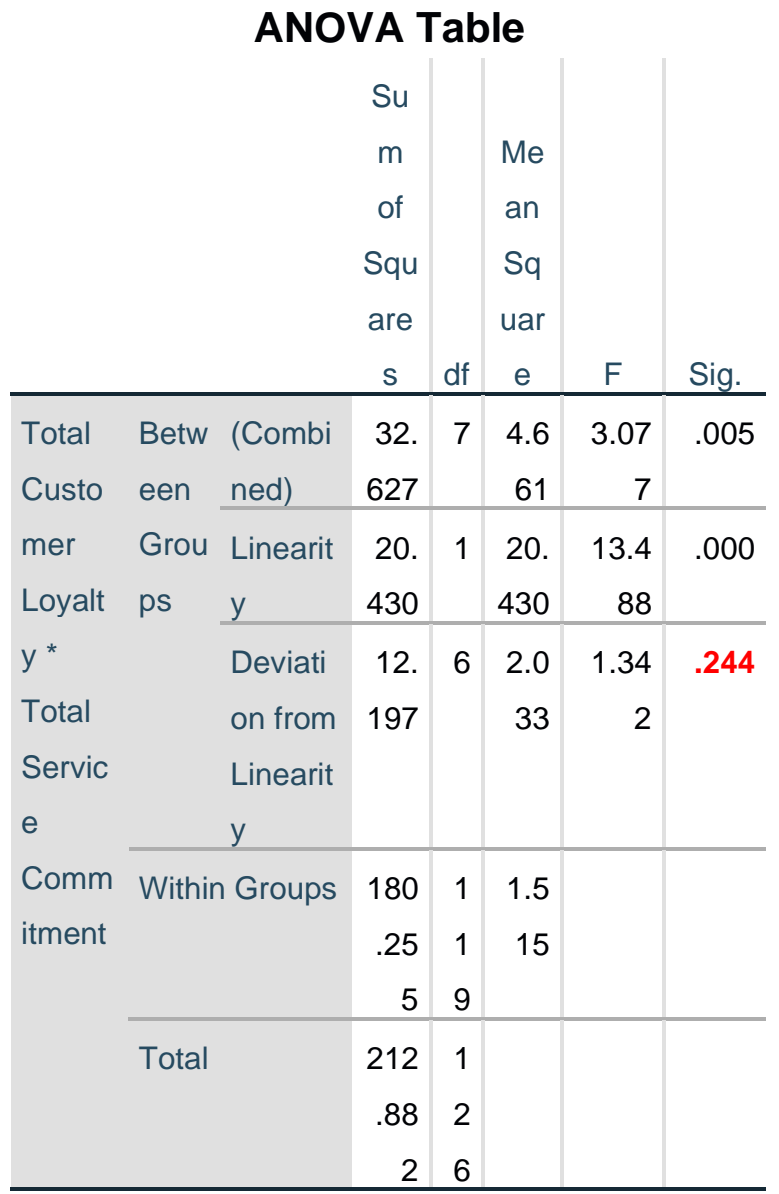

Based on the calculation results, it could be seen that the Deviation from Linearity Sig. > 0.05, 0.258 to be exact, then there was a significant linear relationship between service communication variables and customer loyalty variables.

- The linearity test results of the conflict handling variable on customer loyalty

Based on the calculation results, it could be seen that the Deviation from Linearity Sig. > 0.05, 0.103 to be exact, then there was a significant linear relationship between the conflict handling variable and the customer loyalty variable.

The linearity test results of service communication variables on customer loyalty

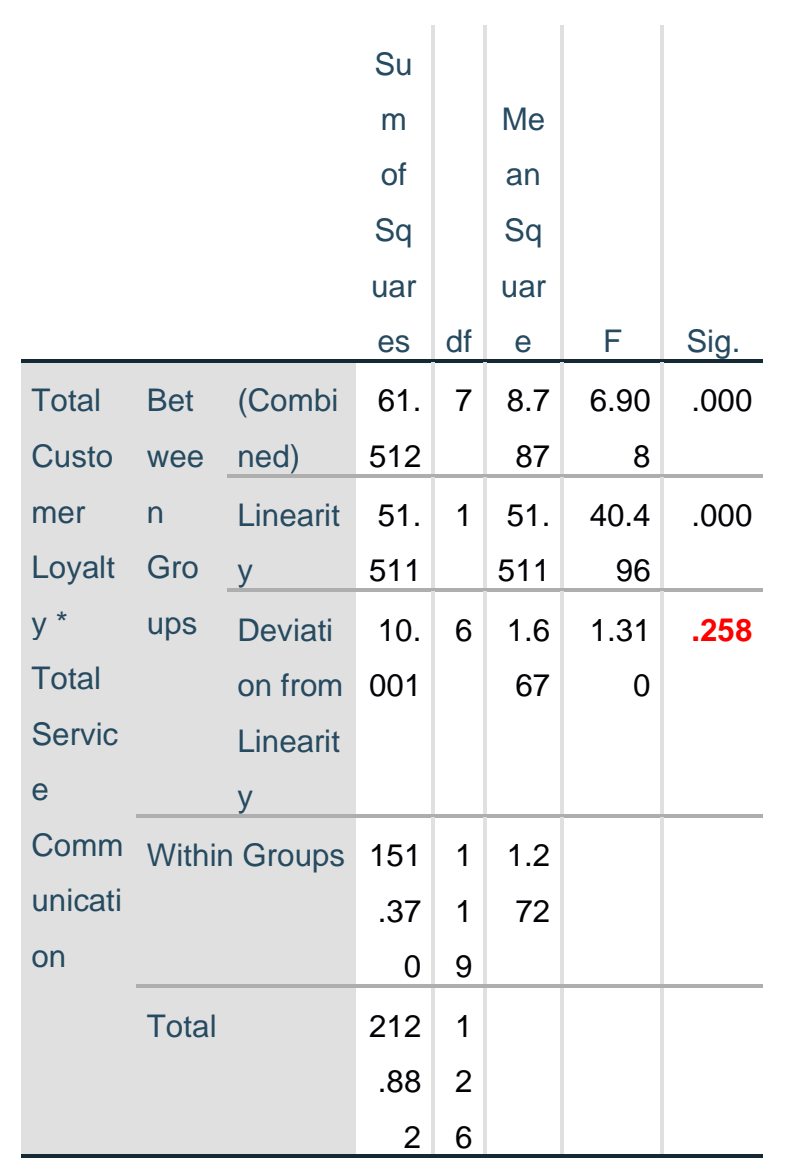

Based on the calculation results, it could be seen that the Deviation from Linearity Sig. $>0.05,0.258$ to be exact, then there was a significant linear relationship between service communication variables and customer loyalty variables.

- The linearity test results of the conflict handling variable on customer loyalty 


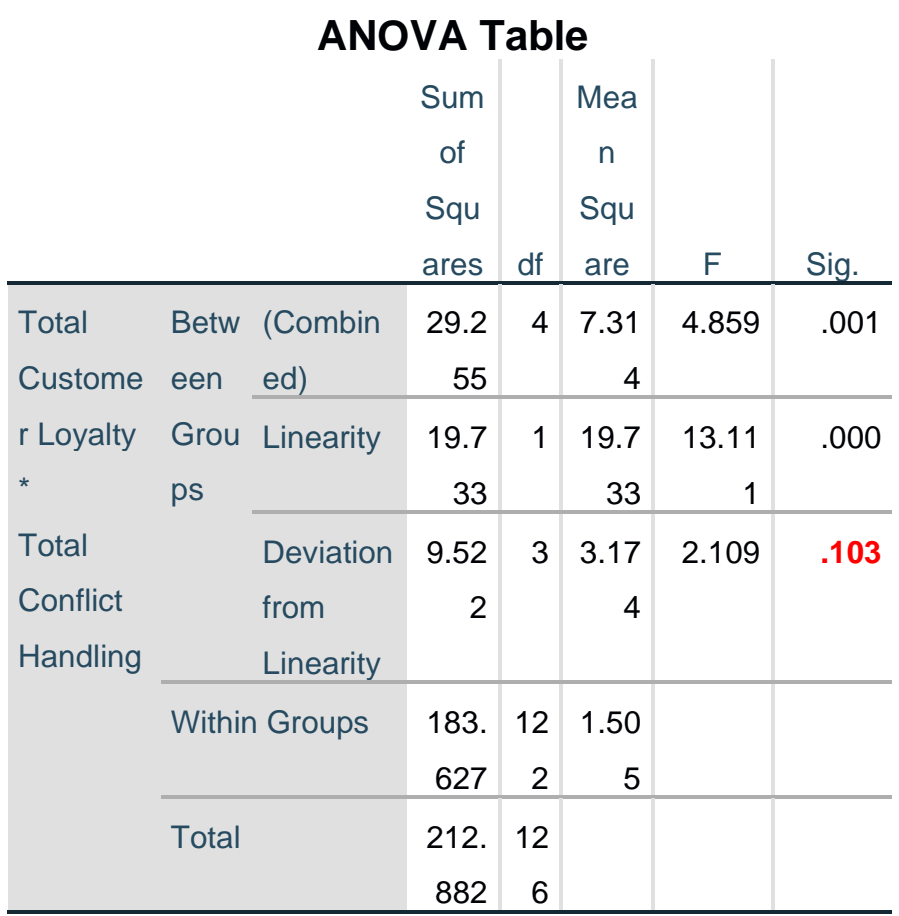

Based on the calculation results, it could be seen that the Deviation from Linearity Sig. > 0.05, 0.103 to be exact, then there was a significant linear relationship between the conflict handling variable and the customer loyalty variable.

\section{Multicollinearity Test Results}

The researcher conducted a multicollinearity test to find out that there was no correlation between the independent variables. The basis for decision making in the multicollinearity test are;

a. The basis for the decision based on the Tolerance value:

1. If the tolerance value was $>0.10$, it meant that there was no multicollinearity in the regression model

2 . If the tolerance value was $<0.10$, it meant that there was multicollinearity in the regression model

b. The basis for the decision based on VIF value:

1. If the VIF value was $<10.00$, it meant that there was no multicollinearity in the regression model
2. If the VIF value was $>10.00$, it meant that there was multicollinearity in the regression model

\begin{tabular}{|c|c|c|c|c|c|c|}
\hline $\begin{array}{c}\text { Indepe } \\
\text { ndent } \\
\text { Variab } \\
\text { le }\end{array}$ & $\begin{array}{c}\text { Depe } \\
\text { nden } \\
\text { t } \\
\text { Varia } \\
\text { bel }\end{array}$ & $\begin{array}{c}\text { Colli } \\
\text { neari } \\
\text { ty } \\
\text { Toler } \\
\text { ance } \\
\text { Valu } \\
\text { e }\end{array}$ & $\begin{array}{c}\text { Toler } \\
\text { ance } \\
\text { Value } \\
\text { Requi } \\
\text { remen } \\
\text { t }\end{array}$ & $\begin{array}{l}\text { V } \\
\text { I } \\
\text { F }\end{array}$ & $\begin{array}{c}\text { VI } \\
\text { F } \\
\text { Re } \\
\text { qu } \\
\text { ir- } \\
\text { e } \\
\text { m } \\
\text { en } \\
\text { t }\end{array}$ & $\begin{array}{l}\text { Val } \\
\text { ue }\end{array}$ \\
\hline Trust & \multirow{4}{*}{$\begin{array}{l}\text { Custo } \\
\text { mer } \\
\text { Loyal } \\
\text { ty }\end{array}$} & 0.997 & $>0.10$ & $\begin{array}{l}1 . \\
\mathbf{0} \\
\mathbf{0} \\
\mathbf{3}\end{array}$ & $\begin{array}{c}<1 \\
0.0 \\
0\end{array}$ & $\begin{array}{c}\text { Un } \\
\text { occ } \\
\text { ur }\end{array}$ \\
\hline $\begin{array}{c}\text { Commi } \\
\text { tment }\end{array}$ & & 0.907 & $>0.10$ & $\begin{array}{l}1 . \\
1 \\
0 \\
2\end{array}$ & $\begin{array}{c}<1 \\
0.0 \\
0\end{array}$ & $\begin{array}{c}\text { Un } \\
\text { occ } \\
\text { ur }\end{array}$ \\
\hline $\begin{array}{l}\text { Commu } \\
\text { nication }\end{array}$ & & 0.953 & $>0.10$ & $\begin{array}{l}1 . \\
\mathbf{0} \\
4 \\
9\end{array}$ & $\begin{array}{c}<1 \\
0.0 \\
0\end{array}$ & $\begin{array}{c}\text { Un } \\
\text { occ } \\
\text { ur }\end{array}$ \\
\hline $\begin{array}{c}\text { Conflic } \\
\mathrm{t} \\
\text { Handlin } \\
\mathrm{g}\end{array}$ & & 0.903 & $>0.10$ & $\begin{array}{l}1 . \\
1 \\
0 \\
7\end{array}$ & $\begin{array}{c}<1 \\
0.0 \\
0\end{array}$ & $\begin{array}{l}\text { Un } \\
\text { occ } \\
\text { ur }\end{array}$ \\
\hline
\end{tabular}

Based on the calculation results of the multicollinearity test, it showed that there were no symptoms of multicollinearity in all variables of this study. The decision was made based on the terms of the tolerance value which the overall result of the calculation showed the number $>0.10$ and also the VIF value which showed the result $<10.00$.

\section{Heteroscedasticity Test Results}

The results of the heteroscedasticity test were carried out by comparing the results of significance (Sig.). If the results showed a number greater than 0.05 , then there was no symptom of heteroscedasticity in the regression model in this study and vice versa. 


\begin{tabular}{|c|c|c|}
\hline Variabel & $\begin{array}{c}\text { Hasil } \\
\text { Hitung }\end{array}$ & Keterangan \\
\hline Trust & 0.184 & $\begin{array}{c}\text { There are no } \\
\text { symptoms of } \\
\text { heteroscedasticity }\end{array}$ \\
\hline Commitment & 0.129 & $\begin{array}{c}\text { There are no } \\
\text { symptoms of } \\
\text { heteroscedasticity }\end{array}$ \\
\hline Communication & 0.743 & $\begin{array}{c}\text { There are no } \\
\text { symptoms of } \\
\text { heteroscedasticity }\end{array}$ \\
\hline $\begin{array}{c}\text { Conflict } \\
\text { Handling }\end{array}$ & 0.623 & $\begin{array}{c}\text { There are no } \\
\text { symptoms of } \\
\text { heteroscedasticity }\end{array}$ \\
\hline
\end{tabular}

Based on the calculation results, it could be seen that the calculated significance (Sig.) of all variables shows a number greater than 0.05 , it meant there was no symptom of heteroscedasticity in all the variables studied.

\section{Multiple Linear Regression Analysis Test}

Multiple linear tests were carried out to determine the relationship between the independent variable $(X)$ and the dependent variable $(\mathrm{Y})$ both simultaneously and individually/partially.

\section{Simultaneous F Test Results}

\begin{tabular}{|c|c|c|c|c|c|c|}
\hline & & & OV & & & \\
\hline & & $\begin{array}{l}\text { Sum of } \\
\text { Squares }\end{array}$ & $\mathrm{df}$ & $\begin{array}{l}\text { Mean } \\
\text { Square }\end{array}$ & $\mathrm{F}$ & Sig. \\
\hline 1 & $\begin{array}{l}\text { Regres } \\
\text { sion }\end{array}$ & 70,802 & 4 & 17,700 & $\begin{array}{r}15,1 \\
99\end{array}$ &, $000^{\mathrm{b}}$ \\
\hline & $\begin{array}{l}\text { Residu } \\
\text { al }\end{array}$ & 142,080 & 122 & 1,165 & & \\
\hline & Total & 212,882 & 126 & & & \\
\hline
\end{tabular}

a. Dependent Variable: Total Customer Loyalty

b. Predictors: (Constant), Total Conflict Handling,

Total Customer Trust, Total Service Communication, Total Service Commitment
Based on the results of the calculation in the table above, it shows the results of 15,199 . Furthermore, the researcher looks for the results of the $F$ table with the formula;

Fcount 15.199

Ftable $=(\mathrm{k} ; \mathrm{n}-\mathrm{k})$

$=(4 ; 100-4)$

$=(4 ; 96)$

Note:

$\mathrm{k}=$ number of independent variables $=4$

$\mathrm{n}=$ number of respondents $=100$

Based on the formula above, it was known that the result of the Ftable is 2.47. If we looked at the comparison between Ftable and Fcount, it could be concluded that Fcount $>$ Ftable so it could be concluded that there was a relationship between the variables of customer trust, service commitment, service communication and conflict handling simultaneously (together) and the customer loyalty variable.

\section{Result of Determination Coefficient Test ( $\mathbf{R}_{\text {square }}$ )}

\begin{tabular}{ll|r|r|r}
\multicolumn{7}{c}{ Model Summary } \\
Model & $\mathrm{R}$ & \multicolumn{1}{c}{$\begin{array}{c}\text { R } \\
\text { Square }\end{array}$} & $\begin{array}{c}\text { Adjusted R } \\
\text { Square }\end{array}$ & $\begin{array}{l}\text { Std. Error of } \\
\text { the Estimate }\end{array}$ \\
\hline 1 &, $577^{\mathrm{a}}$ &, 333 &, 311 & 1,079 \\
\hline
\end{tabular}

a. Predictors: (Constant), Total of Conflict Handling,

Total of Customer Trust, Total of Service

Communication, Total of Service Commitment

Based on the calculation results, it could be seen that the amount of the relationship simultaneously between the variables of trust, commitment, communication and conflict handling on customer loyalty variable was 0.333 or $33.3 \%$. This figure was based on the results of the Rsquare coefficient which is based on the formula:

$$
\begin{aligned}
& R_{\text {square }}=\mathrm{R} \times \mathrm{R} \\
& =0.577 \times 0.577 \\
& =0,333 \\
& =33,3 \%
\end{aligned}
$$


$\alpha=5 \%$ or 0,05

This figure means that the variables of trust, commitment, communication and conflict handling simultaneously could influence the customer loyalty variable by $33.3 \%$, while the remaining $76.7 \%$ was influenced by other variables not examined in this study.

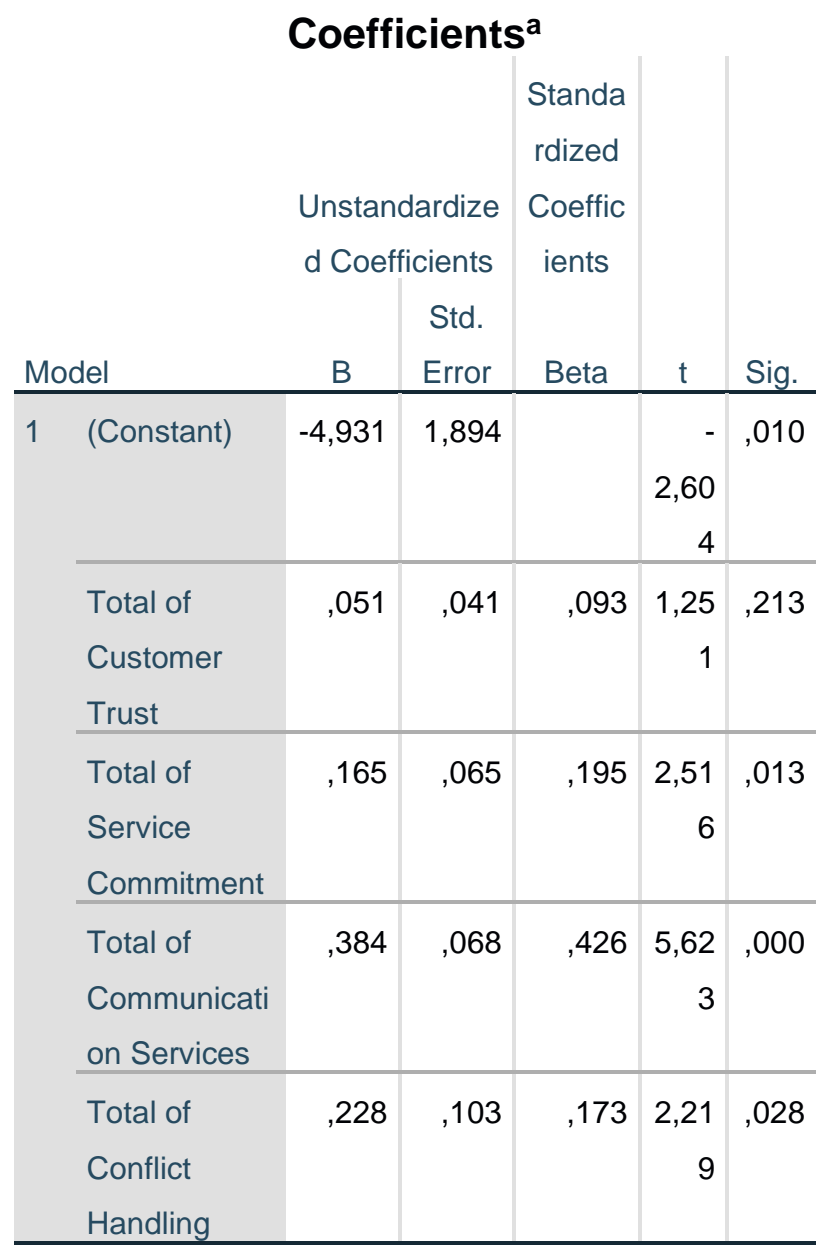

a. Dependent Variable: Total Customer Loyalty

\section{T Test Result (Partial)}

Researchers calculate the value of $\mathrm{T}$ table with the following formula;

$\mathrm{T}$ tabel $=(\alpha / 2: \mathrm{n}-\mathrm{k}-1)$

$=(0,05 / 2):(100-4-1)$

$=0,025 ; 95$

$=1,98552$

Note:

$\mathrm{k}=$ number of independent variables $=4$

$\mathrm{n}=$ number of respondents $=100$
After making a decision, the researcher then looks at the relationship between variable $\mathrm{X}$ and variable $\mathrm{Y}$;

1. The relationship between the variables of customer trust and customer loyalty. If we compared the $\mathrm{T}_{\text {table }}$ with $\mathrm{T}_{\text {count }}$ on the customer loyalty variable, it could be seen that the $\mathrm{T}_{\text {count }}$ value was 1.251 in other words, the $\mathrm{T}_{\text {count }}$ value $(1.251)<\mathrm{T}_{\text {table }}(1.98552)$, therefore it could be concluded that there was no significant relationship between the trust variable and the customer loyalty variable.

2. The relationship between the variable service commitment and customer loyalty. If we compared the $\mathrm{T}_{\text {table }}$ with $\mathrm{T}_{\text {count }}$ on the customer loyalty variable, it could be seen that the $\mathrm{T}_{\text {count }}$ value was 2.516 in other words, the $\mathrm{T}_{\text {count }}$ value (2.516) $>\mathrm{T}_{\text {table }}(1.98552)$, therefore it could be concluded that there was a significant relationship between the commitment variable and the customer loyalty variable.

3. The relationship between service communication variables and customer loyalty. If we compared the $\mathrm{T}_{\text {table }}$ with $\mathrm{T}_{\text {count }}$ on the customer loyalty variable, it could be seen that the $\mathrm{T}_{\text {count }}$ value was 5.623 in other words, the $\mathrm{T}_{\text {count }}$ value $(5.623)>$ $\mathrm{T}_{\text {table }}(1.98552)$, therefore it could be concluded that there was a relationship between the communication variable and the customer loyalty variable.

4. The relationship between conflict handling variables and customer loyalty. If we compared the $\mathrm{T}_{\text {table }}$ with $\mathrm{T}_{\text {count }}$ on the customer loyalty variable, it could be seen that the $\mathrm{T}_{\text {count }}$ value is 2,219 in other words, the $\mathrm{T}_{\text {count }}$ value $(2,219)>$ $\mathrm{T}_{\text {table }}(1,98552)$, therefore it could be concluded that there was a relationship between conflict handling variables and customer loyalty variables. 
After the researcher knows the relationship between the four variables $\mathrm{X}$ and the $\mathrm{Y}$ variable partially, the researcher enters the relationship into the regression equation formula;

$\mathrm{Y}=\alpha+\beta 1 \mathrm{X} 1+\beta 2 \mathrm{X} 2+\beta 3 \mathrm{X} 3+\beta 4 \mathrm{X} 4+\mathrm{e}$

$\mathrm{Y}=-4,931+0,051 \mathrm{X} 1+0,165 \mathrm{X} 2+0,384 \mathrm{X} 3+0,228 \mathrm{X} 4+\mathrm{e}$

Note

$\mathrm{Y}:$ Decision process

$\alpha$ : Konstanta

$\mathrm{X} 1$ : Trust

X2: Commitment

$\mathrm{X}$ : Communication

$\mathrm{X} 4$ : Conflict handling

$\beta 1, \beta 2, \beta 3, \beta 4$ : Regression coefficient (shows the rate of increase or decrease in the dependent variable based on the relationship between the values of the independent variable)

e: Standard error

1. If other variables were constant, the $\mathrm{Y}$ value will change by itself at a constant value of $-4,931$

2. If other variables were constant, the $\mathrm{Y}$ value will change by 0.51 for each $\mathrm{X} 1$ unit

3. If other variables were constant, the $\mathrm{Y}$ value will change by 0.165 for each $\mathrm{X} 2$ unit

4. If other variables were constant, the $\mathrm{Y}$ value will change by 0.384 for each X3 unit

5. If other variables were constant, the $\mathrm{Y}$ value will change by 0.228 for each $\mathrm{X} 4$ unit

It can be concluded based on the table along with the formula above that;

1. There is no relationship between customer trust variables and customer loyalty variables at Plaza Toyota Workshop Bandung

2. There is a significant and positive relationship between the service commitment variable and customer loyalty at Plaza Toyota Workshop Bandung
3. There is a significant and positive relationship between service communication variables and customer loyalty variables at Plaza Toyota Workshop Bandung 4. There is a significant and positive relationship between conflict handling and customer loyalty at Plaza Toyota Workshop Bandung

\section{Discussion According to the Average Index}

\begin{tabular}{|c|c|c|c|c|}
\hline Variabel & Pertanyaan & IR & Ranking & Pernyataan \\
\hline \multirow{6}{*}{$\begin{array}{c}\text { Kepercayaan } \\
\text { Pelanggan }\end{array}$} & 1 & 4.00 & 13 & Bengkel Plaza Toyota Bandung memberikan rasa aman kepada pelanggan dalam pelayanan jasa service \\
\hline & 2 & 3.76 & 16 & $\begin{array}{l}\text { Janji Bengkel Plaza Toyota Bandung yang diberikan kepada Saya dapat dipercaya (Harga yang } \\
\text { dibayarkan sesuai dengan estimasi yang diinformasikan diawal }\end{array}$ \\
\hline & 3 & 3.46 & 18 & $\begin{array}{l}\text { Bengkel Plaza Toyota Bandung memberikan layanan sesuai dengan harapan saya (contoh; Bengkel } \\
\text { Plaza Toyota Bandung memberikan garansi terhadap service yang dilakukan pada kendaraan Saya) }\end{array}$ \\
\hline & 4 & 3.30 & 19 & Petugas Bengkel Plaza Toyota Bandung menunjukkan rasa hormat kepada Saya \\
\hline & 5 & 3.70 & 17 & $\begin{array}{l}\text { Bengkel Plaza Toyota Bandung memenuhi kewajibannya dalam untuk melakukan service rutin } \\
\text { kendaraan mengingatkan Saya }\end{array}$ \\
\hline & 6 & 4.10 & 12 & $\begin{array}{l}\text { Saya merasa nyaman terhadap pelayanan yang diberikan oleh Bengkel Plaza Toyota Bandung } \\
\text { kepada Saya }\end{array}$ \\
\hline \multirow{4}{*}{$\begin{array}{l}\text { Komitmen } \\
\text { Pelayanan }\end{array}$} & 7 & 4.20 & 8 & Bengkel Plaza Toyota Bandung sudah mempersiapkan segala jenis kebutuhan yang Saya butuhkan \\
\hline & 8 & 4.00 & 13 & $\begin{array}{l}\text { Bengkel Plaza Toyota Bandung memberikan layanan service secara personal untuk memenuhi } \\
\text { kebutuhan Saya (Saya dapat memilih teknisi maupun service advisor yang biasa menangani }\end{array}$ \\
\hline & 9 & 4.00 & 13 & $\begin{array}{l}\text { Bengkel Plaza Toyota Bandung memiliki kebijakan yang fleksibel ketika Saya merubah jenis service } \\
\text { yang Saya inginkan terhadap kendaraan Saya }\end{array}$ \\
\hline & 10 & 4.20 & 8 & Bengkel Plaza Toyota Bandung memberikan fleksibilitas dalam melayani kebutuhan Saya \\
\hline \multirow{4}{*}{$\begin{array}{c}\text { Komunikasi } \\
\text { Pelayanan }\end{array}$} & 11 & 4.14 & 11 & Bengkel Plaza Toyota Bandung memberikan informasi yang tepat dan dapat dipercaya \\
\hline & 12 & 4.35 & 3 & Bengkel Plaza Toyota Bandung memberikan informasi ketika terdapat jenis pelayanan baru \\
\hline & 13 & 4.24 & 6 & $\begin{array}{l}\text { Bengkel Plaza Toyota Bandung membuat dan memenuhi janji yang diberikan kepada Saya (Waktu } \\
\text { pengerjaan service yang dijanjikan oleh Bengkel Plaza Toyota Bandung sesuai dengan yang telah }\end{array}$ \\
\hline & 14 & 4.23 & 7 & Informasi yang diberikan oleh Bengkel Plaza Toyota Bandung kepada Saya selalu akurat \\
\hline \multirow{3}{*}{$\begin{array}{c}\text { Penanganan } \\
\text { Masalah }\end{array}$} & 15 & 4.27 & 5 & Bengkel Plaza Toyota Bandung selalu memberikan informasi terkait tindakan yang akan dilakukan \\
\hline & 16 & 4.51 & 1 & $\begin{array}{l}\text { Bengkel Plaza Toyota Bandung berusaha untuk memberikan solusi yang tepat terhadap } \\
\text { permasalahan pada kendaraan Saya sebelum masalah tersebut berkembang menjadi masalah yang }\end{array}$ \\
\hline & 17 & 4.39 & 2 & $\begin{array}{l}\text { Bengkel Plaza Toyota Bandung mendiskusikan solusi yang diberikan kepada Saya ketika terdapat } \\
\text { masalah pada kendaraan Saya }\end{array}$ \\
\hline \multirow[b]{2}{*}{$\begin{array}{c}\text { Loyalitas } \\
\text { Pelanggan }\end{array}$} & 18 & 4.20 & 8 & Saya akan memilih Bengkel Plaza Toyota Bandung sebagai Bengkel pilihan pertama Saya \\
\hline & 19 & 4.30 & 4 & $\begin{array}{l}\text { Bengkel pertama yang Saya ingat ketika ingin melakukan service kendaraan adalah Bengkel Plaza } \\
\text { Toyota Bandung }\end{array}$ \\
\hline
\end{tabular}

The top rank was occupied by the problem handling variable statement. This indicates that loyalty really depends on how Plaza Toyota Workshop Bandung was able to provide solutions, discuss how to handle problems, as well as information provided to customers on how to handle problems that occur. This can be proven from the ranking which shows the question items on the conflict handling variable are in the top 5 (five) rank.

Various forms of communication related to the provision of information related to service dues, reschedule of service dues, the accuracy of information and the accuracy of estimates provided to customers are the next strongest

factor affecting customer loyalty at the Plaza Toyota Workshop Bandung. 
The service commitment provided to customers at Plaza Toyota Workshop Bandung, from the preparations made to the policies given to customers is a factor that strengthens customer loyalty who uses services at Plaza Toyota Workshop Bandung.

Customer trust did not have a big impact on customer loyalty. It could be seen that of the 6 (six) question items, almost all of them were in the lowest ranking. It could also be indicated that the customer no longer doubts the services provided by the Plaza Toyota Bandung Workshop. Services that fit your needs, sense of security, promises given, hospitality of the securities, to the comfort of customers have no influence on loyalty because Plaza Toyota Workshop Bandung has consistently done this so that it causes the variable customer trust to have no significant impact on customer loyalty.

\section{IV.CONCLUSION}

PT Toyota Astra Motor (TAM) is a Toyota Brand Sole Agent Holder which has long been the largest market share holder in Indonesia. Plaza Toyota Workshop Bandung has an important contribution in achieving the annual performance of PT Toyota Astra Motor (TAM) in the West Java region.

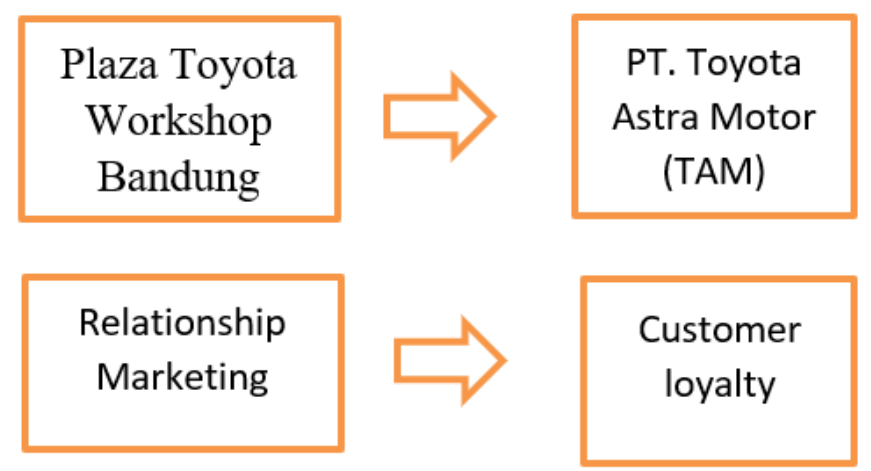

From this research, it was found that the relationship marketing dimension, namely customer trust, did not affect customer loyalty at Plaza Toyota Workshop Bandung, but service commitment, service communication and conflict handling affect customer loyalty at Plaza Toyota Workshop Bandung.
Relationships that were in line and also mutually reinforcing between one another could be used as a reference for Plaza Toyota Workshop Bandung to increase loyalty and had an impact on increasing entry service units (the number of vehicles that carry out routine maintenance) at Plaza Toyota Workshop Bandung.

\section{SUGGESTION}

Suggestions for Plaza Toyota Workshop Bandung

1. To be more active in implementing customer reminder activities to do routine maintenance of vehicles carried out by Maintenance Reminder Appointment (MRA), these activities could be done more to increase customer loyalty.

2. Plaza Toyota Workshop Bandung should understand what is needed by its customers and improve service quality. By improving the quality of service, the commitment between Plaza Toyota Workshop Bandung and its customers can be well established.

3. Plaza Toyota Workshop Bandung should further improve the way of information delivery to customers so information can be received by customers quickly, precisely and accurately. This information can be conveyed through various media, considering that at this time we are in a digital era and rapidly advancing technology, so information attainment should be done through online media such as websites, Instagram, whats app and others.

4. Plaza Toyota Workshop Bandung should be able to improve problem handling services by taking a broader approach to customers in preventing and dealing with all the problems that occur in customer's Toyota vehicles. The handling of these complaints can be improved by providing facilities and media that can directly accommodate any complaints from customers, providing special applications for receiving customer complaints so that customers can submit their complaints anytime and anywhere. 


\section{Suggestions for Further Research}

In this section the authors hope to hold further research with qualitative methods in order to support the results that have been researched in this study. The researcher recommends it because the researcher realizes there are deficiencies in this study, because the lack of information about the dimensions of relationship marketing to customer loyalty at Plaza Toyota Workshop Bandung.

\section{VI.REFERENCES}

[1]. Jafarzadeh Chan, S (2003). Relationship Marketing : Inovasi Pemasaran yang Membuat Pelanggan Bertekuk Lutut. PT. Gramedia Pustaka Utama, Jakarta

[2]. Egan John. "Relationship Marketing Exploring relational strategies in Marketing"

[3]. Ehigie, Benjamin Osayawe dan Taylor, Megan. "Managing Student's Loyalty to School After Graduation Through Relationship Marketing", The TQM Journal, Vol. 21, No. 5, 2009.

[4]. Edisi Empat, Prentice Hall, England, 2011 Kotler, Philip., and Keller Kevin Lane. (2006). Marketing Management Pearson International Edition, Twelfh Edition. Singapore: Prentice Hall

[5]. Kotler, Philip dan Kevin Lane Keller (2009). Manajemen Pemasaran. Jakarta:Erlangga

[6]. Morgan, Robert M dan Shelby D. Hunt (1994). The Commitment-trust Theory of Relationship
Marketing. Journal of Marketing Vol. 58, July 1994: 20-38

[7]. Ndubisi, N.O. (2007). Relationship Marketing and Customer Loyalty. Marketing Intelligence and Planning, Vol 25, No. 1, 2007, pp. 98-106. From Emerald Group Publishing Limited

[8]. Sanusi, Anwar. 2011. Metedologi Penelitian Bisnis. Penerbit Salemba Empat: Jakarta Selatan

[9]. Sugiyono (2011). Metode Penelitian Kuantitatif, Kualitatif dan R\&D. Bandung: Alfabeta.

[10]. Santoso, Singgih. (2002). Statistik Parametrik. Cetakan Ketiga. PT Gramedia. Pustaka Utama. Jakarta

[11]. http://pengertiandanartikel.blogspot.com/2017/0 3/pengertian-dan-tujuan-relationship.html diakses pada tanggal 30 Agustus 2019 Pukul 02:49 WIB

[12]. http://billyplazatoyota.blogspot.com/2012/12/visi -dan-misi-plaza-toyota.html diakses pada tanggal 30 Agustus 2019 Pukul 03: 55 WIB

\section{Cite this Article}

Putri Yuliastuti, "The Impact of Relationship Marketing on Customer Loyalty at Plaza Toyota Workshop Bandung", International Journal of Scientific Research in Science and Technology (IJSRST), Online ISSN : 2395-602X, Print ISSN : 2395-6011, Volume 8 Issue 2, pp. 56-70, March-April 2021. Available at doi : https://doi.org/10.32628/IJSRST21826 Crossref Journal URL : https://ijsrst.com/IJSRST21826 